\title{
Survival and growth of Cedrela fissilis (Vell.) in mixed species forest plantations
}

\author{
Sobrevivência e crescimento de Cedrela fissilis (Vell.) \\ em plantios florestais consorciados
}

\author{
Andrea Chizzotti Cusatis ${ }^{1}$, Diego Tyszka Martinez ${ }^{2}$, \\ Luciana Duque Silva ${ }^{3}$ e Antonio Rioyei Higa ${ }^{4}$
}

\begin{abstract}
Resumo
Há uma crescente demanda por plantios florestais que combinem restauração de espécies florestais nativas com retorno econômico a proprietários rurais. Cedrela fissilis é uma espécie nativa brasileira sob risco de extinção com grande potencial ao mercado florestal devido ao alto valor da sua madeira. Contudo, a susceptibilidade ao dano da broca das meliáceas (Hypsipyla grandella) e a geada pode limitar seu cultivo. O objetivo deste trabalho foi avaliar a viabilidade de plantios florestais consorciados de $C$. fissilis com pinus (Pinus taeda). Quatro experimentos consorciados foram plantados em blocos casualizados variando as três condições: presença/ausência de cobertura de $P$. taeda, densidade das mudas de $C$. fissilis e tamanho de clareira. Três medições realizadas em diferentes tempos no decorrer do estudo indicaram que a cobertura das árvores de pinus aumentaram a sobrevivência de $C$. fissilis e clareiras menores foram associadas significativamente com crescimento. O plantio consorciado de $C$. fissilis com cobertura de P. taeda, aos quatro anos de idade, apontaram benefícios silviculturais à primeira espécie. Estudos futuros devem focar em uma redução dos níveis de estresse durante o crescimento, seleção de material genético e integração das técnicas apropriadas de silvicultura ao manejo local.
\end{abstract}

Palavras-chave: Cedro-rosa. Meliaceae. Domesticação. Espécie nativa. Modelos lineares mistos.

\begin{abstract}
There is an increasing demand for forest plantations that combine the restoration of native tree species with economic return for landowners. Cedrela fissilis is an endangered native species in Brazil with a great potential to the forestry industry due to its high timber value. However, its susceptibility to damage from the mahogany shoot borer (Hypsipyla grandella) and frost may restrict its forestry application. The aim of this study was to evaluate the viability of $C$. fissilis plantation under mixed-species forest plantations with the loblolly pine (Pinus taeda). Four experimental mixed plantations were set up in randomized blocks with three varying conditions: presence/absence of $P$. taeda cover, density of $C$. fissilis seedlings, and the size of the clearing area. Three sets of measurements taken at different times during the study indicate that cover from pine trees increased survival of $C$. fissilis, and that smaller clearings were associated with significant growth increments. The mixed-species forest plantation with $C$. fissilis under $P$. taeda coverage at four years of age indicated silvicultural benefits for the first species. Future studies should focus on reducing stress levels during the growth stage, selection of genetic material, and integration of appropriate silvicultural techniques into local management practices.
\end{abstract}

Keywords: Cedro-rosa. Meliaceae. Domestication. Native species. Mixed linear models.

\section{INTRODUCTION}

Human influence on forest ecosystems is increasingly evident throughout the world (NOBLE; DIRZO, 1997). Rapidly expanding population and economic growth in developing regions result in tropical forests being among the most affected (WRIGHT, 2005). The growing sustainability chal-

\footnotetext{
1Pós Doctor. Universidade de Lisboa / Faculty of Sciencies - Campo Grande - 1749016 - Lisboa, Portugal. E-mail: andrea.cusatis@gmail.com.

2PhD Professor. UFMT - Universidade Federal do Mato Grosso / Faculty of Forest Engineering. Fernando Correa avenue, Coxipó - 8060-900 - Cuiabá, MT, Brazil. E-mail: diegotyszka@hotmail.com.

3Associate Professor. USP - Universidade de São Paulo / ESALQ - Escola Superior de Agricultura "Luiz de Queiroz". Padua Dias avenue - 13418-900, Piracicaba, SP, Brazil. E-mail: lucianaduques@usp.br.

${ }^{4} \mathrm{PhD}$ Professor. Universidade Federal do Paraná / Agriculttural Sciences Sector, Forestry Department. Lothário Meissner Street 900 - Jardim Botânico - 80210- 170 - Curitiba, PR, Brazil. E-mail: antonio.higa@gmail.com.
}

Sci. For., Piracicaba, v. 46, n. 119, p. 357-366, set. 2018 DOI: dx.doi.org/10.18671/scifor.v46n119.03 
lenges posed by deforestation, forest degradation, climate change and invasive species (WRIGHT, 2010) conflict with increasing recognition of the multiple economic benefits provided by forests (PEARCE, 2001).

Urgent need for decentralized forest management (AGRAWAL et al., 2008) has stimulated the search for new specific and market-based solutions that combine ecological and economic sustainability. One example of such solution are the recent changes to the Brazilian Forest Code, which requires 21 million hectares of local native forest to be maintained and/or restored as "Reserva Legal" (SOARES FILHO et al., 2013). Apart of compulsory protection of the native forest the legislation also enabled a better system of compensation to landowners and managers. However, forest restoration in Brazil is still problematic, and there is a pressing call for forestry systems that would effectively combine native forest restoration and economic returns.

Mixed-species forestry plantations are potential solutions, as they usually provide a wider range of goods and services than monoculture plantations and may also contribute to biodiversity and natural vegetation recovery (LAMB et al., 2010). The development of such a system is presently constrained by the limited commercial availability of native species (HIGA; SILVA, 2006), and a general lack of knowledge about ecology and appropriate silvicultural techniques (LAMB et al., 2010).

A good candidate for forestry is the cedar (Cedrela fissilis Vell.), an endangered tree species native to Brazil with high value timber (RUSCHEL et al., 2003). In the wild, this species is usually found in low-densities in forest clearings with sufficient light to allow its development (MOSTACEDO; FREDERIKSEN, 1999). These clearings may buffer trees from the negative effects of the mahogany shoot borer (Hypsipyla grandella) (D'OLIVEIRA, 2000) and low temperatures (CARVALHO, 1981; 1982; INOUE, 1972), to which C. fissilis is susceptible. For these reasons, pure stands of this species are not viable (KAGEYAMA; CASTRO, 1989) and general silvicultural principles point to low-density plantation in association with a rapidly developing and cold-resistant species (CARVALHO, 2003; JOHNSON; TARIMA, 1995) such as pine.

Pine plantations are widespread in southern Brazil, and in 2012 they accounted for more than 1.5 million hectares (ABRAF, 2013). Loblolly pine (Pinus taeda) is a cold-resistant pioneer species and therefore a good candidate for mixed plantations with $C$. fissilis. If viable, a mixed $C$. fissilis and $P$. taeda forestry system would serve the triple-purpose of fulfilling the "Reserva Legal" requirements for a planted forested system aimed at restoration; providing income for landowners; and finally improving the species status of an endangered native species.

Here, we evaluate the viability of a C. fissilis - P. taeda forestry until four years of age. Specifically, we experimentally test the impact of clearing size; of $P$. taeda cover and conspecific seedling density on the survival; and branching and growth patterns of $C$. fissilis.

\section{MATERIAL AND METHODS}

The present study was carried out at the Rio Feio $\left(26.503^{\circ} \mathrm{S}, 49.534^{\circ} \mathrm{W}\right)$ and Rio da Veada $\left(26.443^{\circ} \mathrm{S},-49.508^{\circ} \mathrm{W}\right)$ farms in the Rio Negrinho municipality, Santa Catarina, Brazil (Fig. 1). The landscape of the region is hilly, with an average altitude of approximately $800 \mathrm{~m}$. The region has a Mesothermal, warm temperate climate according to the Köppen climate classification, with a historical average temperature of $18.3^{\circ} \mathrm{C}$ and historical average annual precipitation of $1572 \mathrm{~mm}$ (INPE, 2009). Specifically, the temperature and precipitation during the experimental period are represented on figure 2 (data provided by Empresa de Pesquisa Agropecuária e Extensão Rural de Santa Catarina S. A. - EPAGRI).

In each farm, two field tests composed of gridded blocks (grid size $2.0 \times 2.5 \mathrm{~m}$ ) were set up according to the description in Table 1. The plantation of $C$. fissilis occurred at the same time as that of $P$. taeda in the Rio Feio farm (absence of cover) and independently, in a P. taeda plantation of approximately $6.8 \mathrm{~m}$ height (presence of cover), in the Rio da Veada farm. The density of $C$. fissilis seeds varied within farm between blocks and, within each block, individual parcels were defined with varying clearing sizes surrounding each individual $C$. fissilis seed planted. The seeds used for this experiment were collected from trees within the study region (CUSATIS et al., 2013). 


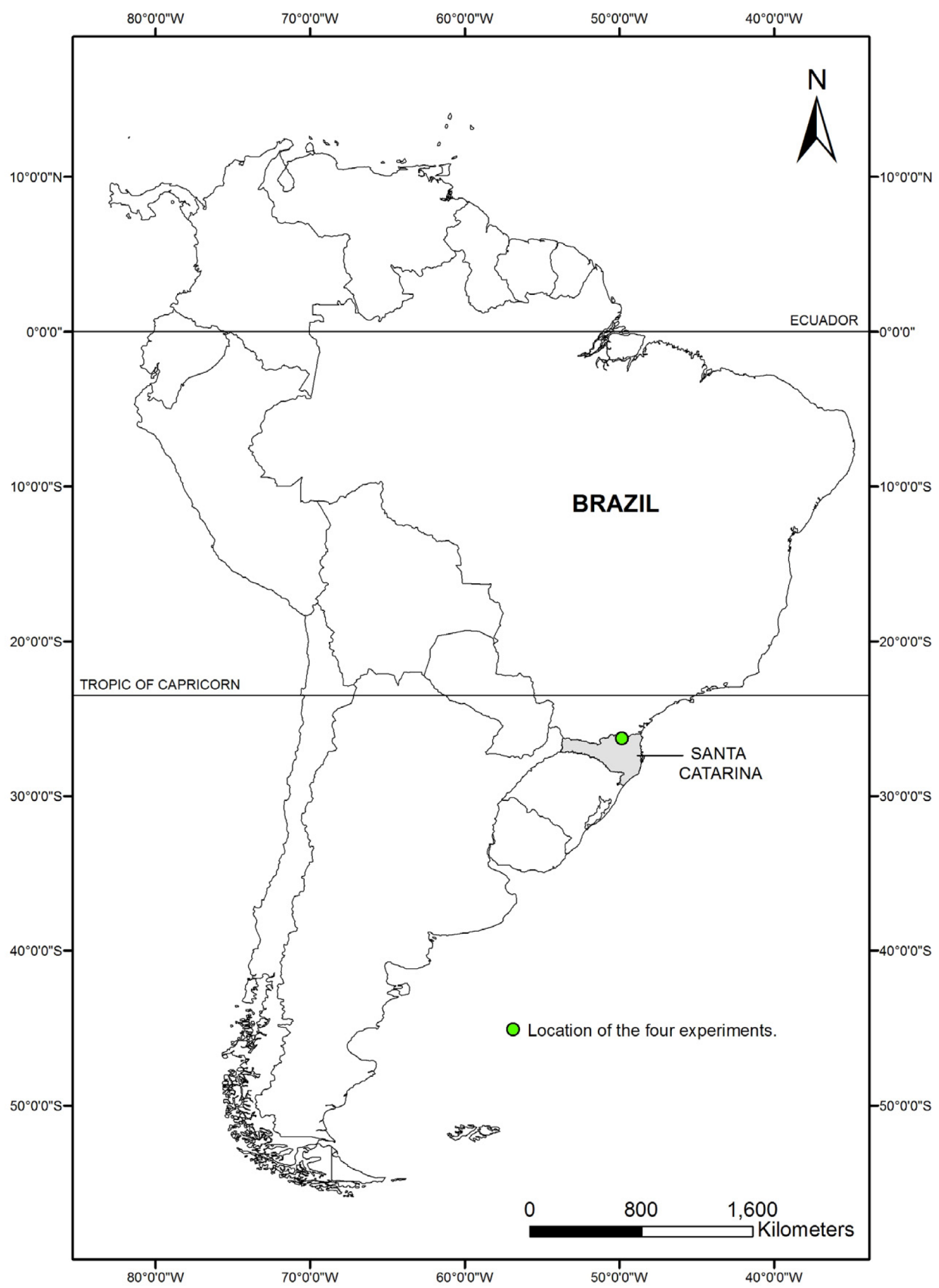

Figure 1. Localização das fazendas com os testes experimentais em Rio Negrinho, Santa Catarina, Brasil. Figura 1. Location of the farms with the field tests in Rio Negrinho, Santa Catarina, Brazil. 


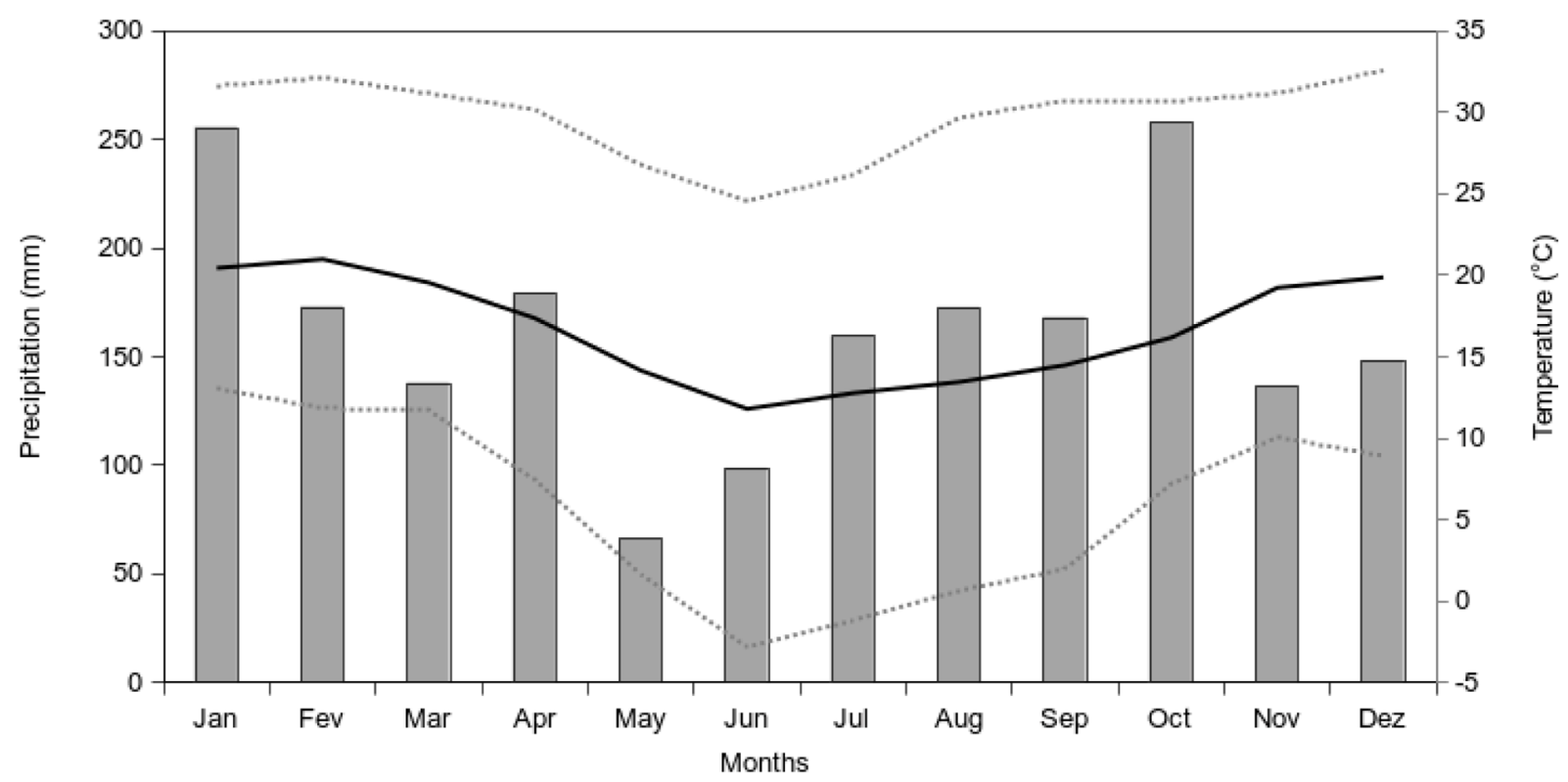

Figure 2. Valores médios mensais entre 2008 a 2011: precipitação média ( $\mathrm{mm}$ ), temperatura média, temperaturas mínimas e máximas $\left({ }^{\circ} \mathrm{C}\right)$ em Rio Negrinho, Santa Catarina, Brazil.

Figura 2. Monthly average values between 2008 and 2011: average precipitation (mm), average temperature, maximum and minimum temperatures $\left({ }^{\circ} \mathrm{C}\right)$ in Rio Negrinho, Santa Catarina, Brazil.

Table 1. Características dos quatro experimentos consorciados de $C$. fissilis e $P$. taeda, plantados em Rio Negrinho, Santa Catarina, Brasil

Tabela 1. Characteristics of the four $C$. fissilis - P. taeda mixed forestry experiments, planted in Rio Negrinho, Santa Catarina, Brazil

\begin{tabular}{|c|c|c|c|c|c|}
\hline Experiment & Farm & Coordinates WGS84 & Cover of $P$. taeda & Tree dens.(tree/ha) & No. blocks \\
\hline 1 & Rio Feio & $\begin{array}{l}\text { O } 49^{\circ} 32^{\prime} 7.747^{\prime \prime} \\
\text { S } 26^{\circ} 30^{\prime} 10.099^{\prime \prime}\end{array}$ & Absent & 37 & 6 \\
\hline 2 & Rio Feio & $\begin{array}{l}\text { O } 49^{\circ} 32^{\prime} 0.222^{\prime \prime} \\
\text { S } 26^{\circ} 30^{\prime} 16.717^{\prime \prime}\end{array}$ & Absent & 67 & 10 \\
\hline 3 & Rio da Veada & $\begin{array}{l}\text { O } 49^{\circ} 30^{\prime} 44.970^{\prime \prime} \\
\text { S } 26^{\circ} 26^{\prime} 30.038^{\prime \prime}\end{array}$ & Present & 37 & 6 \\
\hline 4 & Rio da Veada & $\begin{array}{l}\text { O } 49^{\circ} 30^{\prime} 11.089^{\prime \prime} \\
\text { S } 26^{\circ} 26^{\prime} 39.744^{\prime \prime}\end{array}$ & Present & 67 & 10 \\
\hline
\end{tabular}

The experiment started in November 2008 and measurements were collected 31 (May 2011), 38 (December 2011) and 49 (November 2012) months after the beginning of the field test. Measurements collected for $C$. fissilis included seedling survival (percentage of seedlings), stem diameter $(\mathrm{cm})$, tree height $(\mathrm{cm})$ and trunk branching (percentage of trees). Finally, we also recorded the number of $C$. fissilis individuals that showed signs of disease or damage.

Data analysis followed the analytic framework proposed by Resende and Sturion (2000), using an unbiased estimator of treatment averages that takes into account genotypic and environmental biases in silvicultural experiments. This estimator is based on a Generalized Linear Mixed Model (GLMM) approach and, for a random block design with $t$ treatments, $b$ blocks and $n$ plants per parcel (randomly sampled from a natural population), following the expression:

$$
Y_{i j k}=\mu+t_{j}+b_{j}+e_{i j}+d_{i j k}
$$

in which $\mu$ is the estimated effect error, $t_{i}$ in the treatment effect, $b_{i}$ is the block effect, $e_{i j}$ represents the parcel effect, $d_{i j k}$ the individual effect, and assuming $t_{i}, e_{i j}$ and $d_{i j k}$ as random effects and $b_{i}$ as fixed effect. The mean components estimated by the model are considered the Best Linear Unbiased Predictor (BLUP) (RESENDE, 2007).

This approach was selected because the genotypic variability in the individuals used in the experiment may mask the treatment effect when the sample size is low and the individuals used for the experiment are not genetically identical. Under the BLUP modelling approach, block and individual effects retain most of the genotypic effects, which allows the different treatment effects to be decomposed and statistically compared (RESENDE, 1999; RESENDE; STURION, 2000). 
The analysis was implemented in the software SELEGEN-REML/BLUP (RESENDE, 2007), available for download from the Centre for Studies in Genetics and Plant Breeding, Federal University of Lavras webpage (http://www.nucleoestudo.ufla.br/gen/index.php/donwloads).

\section{RESULTS AND DISCUSSION}

Overall, the survival rates of $C$. fissilis decreased over time under all experimental conditions (Fig. 3 ). Our results produced no evidence of differences in the survival rate of $C$. fissilis in relation to seedling density or clearing size, but the percentage of surviving seedlings was higher in experimental settings under the cover of $P$. taeda in comparison with open canopy plots. Specifically, the average survival rate of $C$. fissilis under the cover of $P$. taeda after 49 months of the experiment was approximately $50 \%$ of all seedlings planted, decreasing to approximately $5 \%$ under no-cover conditions.

37 trees.ha-1 no cover

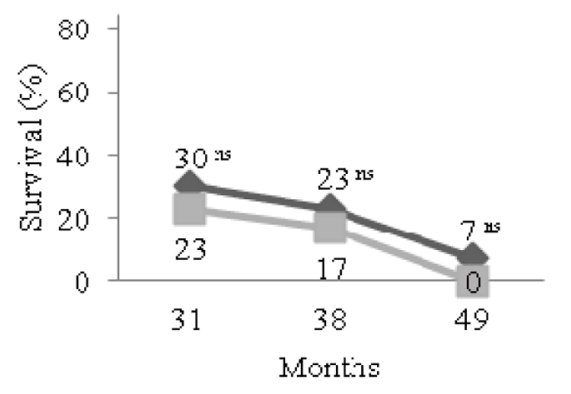

37 trees ha $^{-1}$ under cover

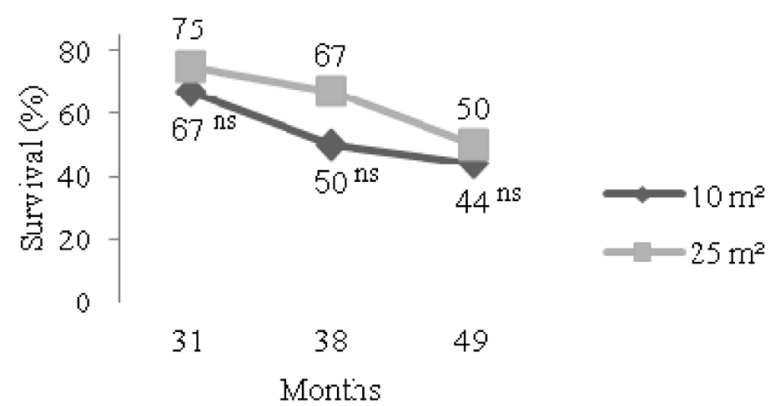

67 trees ha-1 no cover

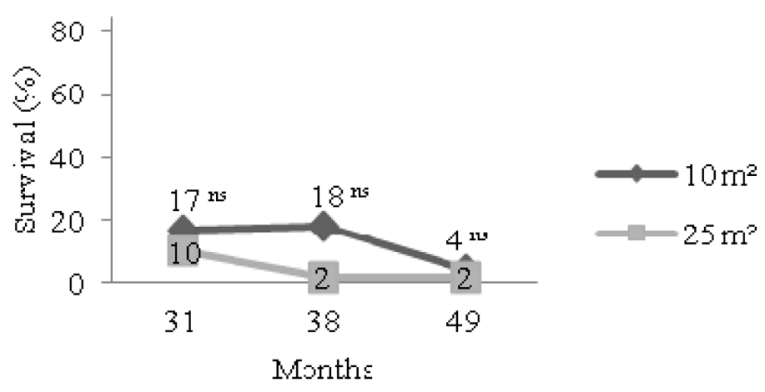

67 trees $h^{-1}$ under cover

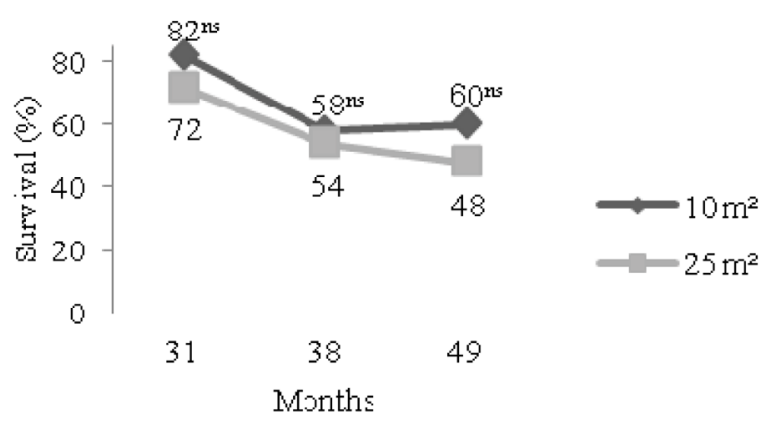

Figure 3. Gráficos ilustrando a taxa de sobrevivência das mudas de $C$. fissilis nos quatros experimentos consorciados de C. fissilis com P. taeda em Rio Negrinho, Santa Catarina, Brasil.

Figura 3. Graphs illustrating the percentage of surviving $C$. fissilis seedlings in the four $C$. fissilis - P. taeda mixed forestry experiments in Rio Negrinho, Santa Catarina, Brazil.

The percentage of surviving $C$. fissilis trees that branched after 49 months was high $(>80 \%)$ under all experimental settings, and no significant differences were found between treatments (Fig. 4). However, it should be noted that the low survival of $C$. fissilis under no-cover conditions did not allow for assessment of branching rate. Nonetheless, the percentage of trees that branched in earlier stages of the experiment suggests that branching rate would remain high under no-cover conditions.

We observed significant differences $(\mathrm{p}<0.05)$ in stem diameter in relation to clearing size under low $C$. fissilis density and under P. taeda cover after 49 months (Fig. 5). In such conditions, stems developed better when $C$. fissilis was planted in larger clearings $\left(25 \mathrm{~m}^{2}\right)$ than in smaller $\left(10 \mathrm{~m}^{2}\right)$ ones. Although we did not find significant differences between the remaining experimental settings, the same trend of stem development was observed under low density and no cover, whereas the opposite trend was observed under higher densities. Once again, statistical comparison of stem diameter development under no-cover conditions at later stages of the experiment was impossible due to the high mortality rate of $C$. fissilis. 


$$
37 \text { trees.ha- } \mathrm{a}^{-1} \text { no cover }
$$

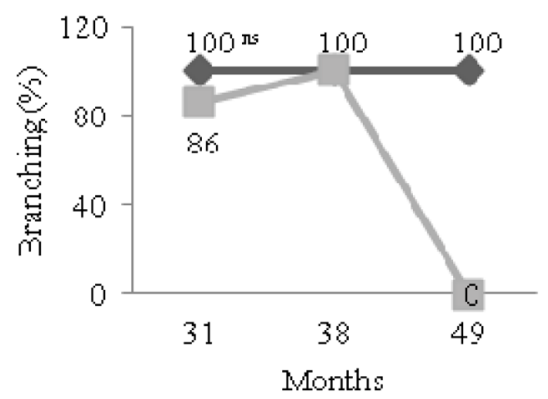

37 trees ha $\mathrm{a}^{-1}$ under cover

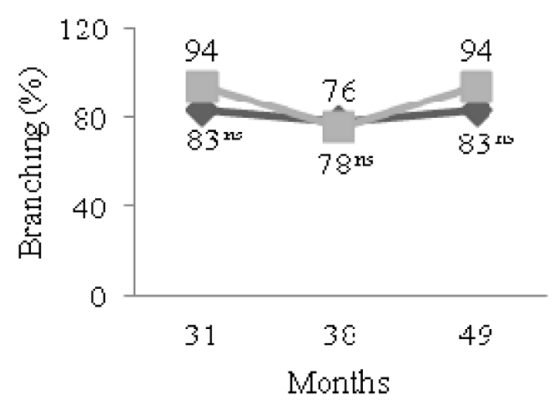

67 trees $^{-1} a^{-1}$ no cover

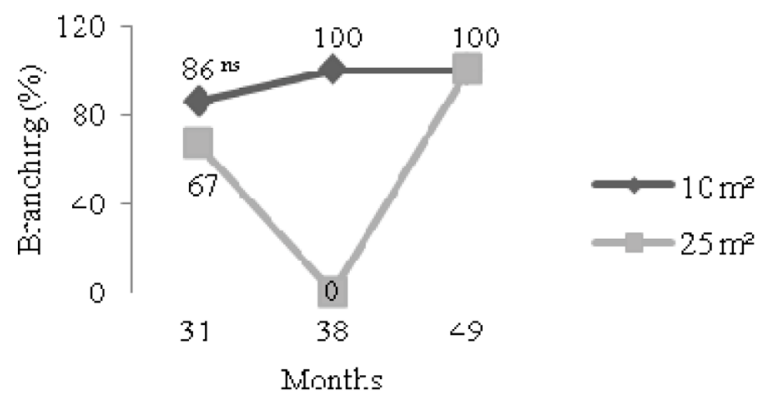

67 trees ha $^{-1}$ under cover

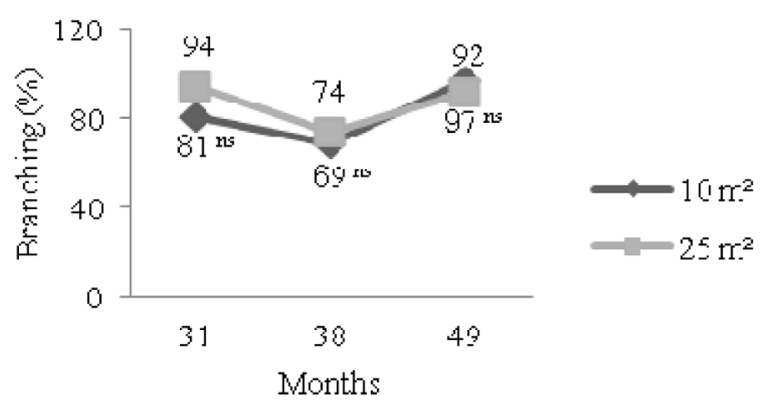

Figure 4. Gráficos ilustrando a taxa de bifurcação das mudas de $C$. fissilis nos quatro experimentos consorciados de C. fissilis com $P$. taeda em Rio Negrinho, Santa Catarina, Brasil.

Figura 4. Graphs illustrating the percentage of $C$. fissilis seedlings that branched in the four $C$. fissilis $-P$. taeda mixed forestry experiments in Rio Negrinho, Santa Catarina, Brazil.

37 trees ha ${ }^{-1}$ no cover

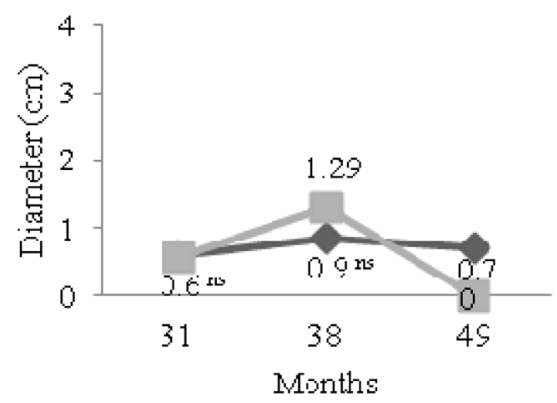

37 trees.ha ${ }^{-1}$ under cover

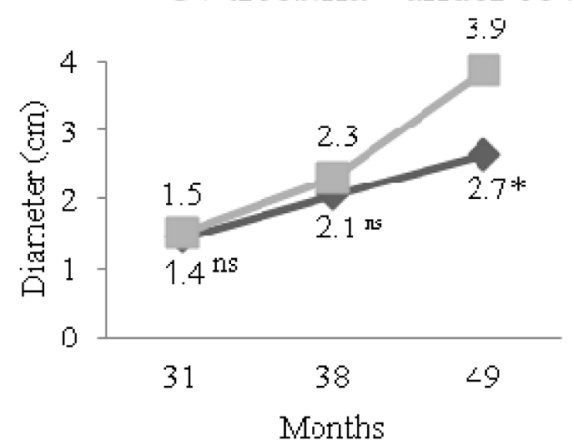

67 trees ha $^{-1}$ no cover

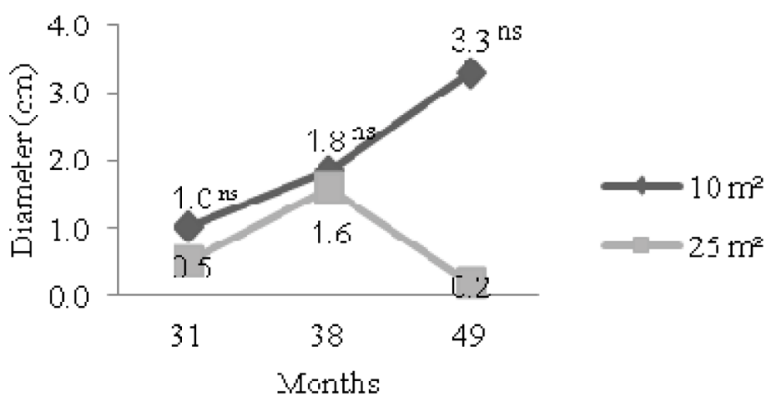

67 trees $^{-1} \mathrm{a}^{-1}$ under cover

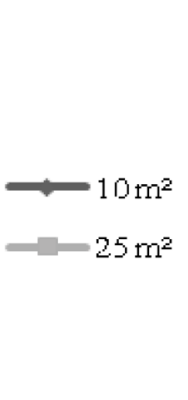

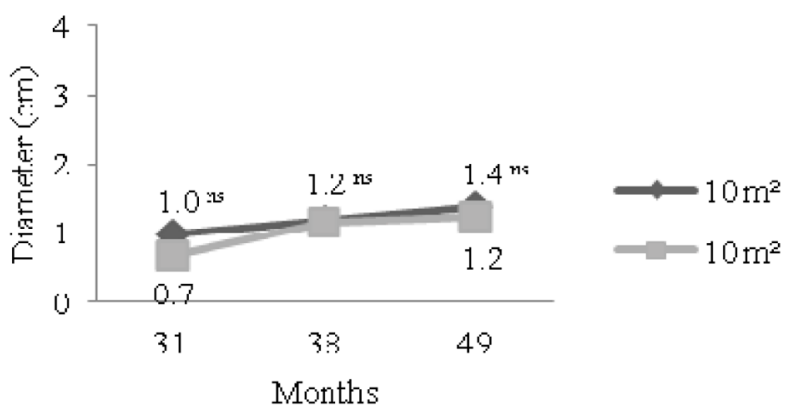

Figure 5. Gráficos ilustrando o diâmetro de colo médio das mudas de $C$. fissilis nos quatro experimentos consorciados de C. fissilis com P. taeda em Rio Negrinho, Santa Catarina, Brasil.

Figura 5. Graphs illustrating the mean stem diameter of $C$. fissilis seedlings in the four $C$. fissilis $-P$. taeda mixed forestry experiments in Rio Negrinho, Santa Catarina, Brazil. 
C. fissilis were taller in smaller clearings throughout the experiment (Fig. 6) and these differences were significant both under cover $(\mathrm{p}<0.01)$ and with no cover $(\mathrm{p}<0.05)$, but only during the earlier experimental stages and under higher seedling density conditions. This is probably a statistical artefact resulting from the high mortality of $C$. fissilis, as later measurements support the trends observed in earlier stages of the experiment. Nevertheless, the mean height of $C$. fissilis seedlings was higher under low seedling densities and no-cover conditions, in line with the pattern observed for the remaining measurements.

Overall, no signs of disease caused by $\mathrm{H}$. grandella were observed in C. fissilis throughout the four experiments. However, several trees showed signs of damage caused by frost and the majority of the affected plants ultimately did not survive.

Our results provide a preliminary but positive prognosis of the viability of a mixed C. fissilis - $P$. Taeda forestry systems in the fourth year. The percentage of $C$. fissilis individuals that survived at the end of the experiment was much higher when planted under the cover of $P$. taeda than when the cover was absent. Furthermore, the mortality rate of $C$. fissilis individuals under cover of $P$. taeda decreased throughout the experiment, but not for individuals planted without any protective cover. Both observations suggest a positive effect of $P$. taeda cover on the establishment of $C$. fissilis, and the presence of protective cover seems to be the most important factor driving the survival of $C$. fissilis throughout the experiment.

None of the C. fissilis trees in the experiment showed any signs of $H$. grandella damage, to which C. fissilis is highly susceptible (D'OLIVEIRA, 2000). Host selection by $H$. grandella is determined by olfactory cues and the presence of other tree species may reduce the ability of the pest to locate its host. While these results do not allow any direct inference regarding the role of $P$. taeda in buffering against the attack of this pest, they provide additional support to earlier suggestions that it may provide a measure of protection (WEAVER; BAUER, 1986).

However, many of the individuals that died during the experiment showed signs of frost damage, suggesting that climate was the main limiting factor for $C$. fissilis survival. C. fissilis is highly susceptible to low temperatures and frost damage (CARVALHO, 1982, 1981; NOUE, 1972). Under-cover plantations are a common recommendation for species that are susceptible to frost (CARVALHO, 1978; INOUE, 1972) and previous studies have demonstrated high survival levels of C. fissilis under the cover of other species (TOLEDO FILHO; PARENTE, 1982). Our study registered higher survival rates of $C$. fissilis individuals planted under the cover of $P$. taeda in comparison to individuals planted without protective cover. These results provide additional support for earlier suggestions that planting under cover may be effective to improve C. fissilis survival (CARVALHO, 2003; JOHNSON; TARIMA, 1995).

Tree branching is a common response to frost stress, both in C. fissilis (CARVALHO, 1982) and other susceptible species such as Allophylus edulis (BIONDI et al., 2007), Balfourodendron riedelianum, Cabralea cangerana, Lafoensia pacari (CARVALHO, 1982) and Eucalyptus dunnii (HIGA et al., 2000). In our experiment, branching was observed in frost-damaged plants: while all $C$. fissilis individuals planted without pine cover had branched by the end of the study, a percentage of covered trees did not branch independently of other experimental settings. This fact suggests that $P$. taeda cover may indeed buffer $C$. fissilis seedlings against frost damage, resulting in reduced stress levels and improved survival.

C. fissilis growth patterns provide a more complex picture. Our results suggest that $P$. taeda cover has a positive effect on $C$. fissilis development, but that clearing size and seedling density may also play an important role. Measurements of stem diameter and tree height were generally higher under experimental conditions of low seedling density and pine cover. We did observe an increase of both variables at later stages of the experiment under higher seedling densities and in absence of cover, but the low number of surviving individuals $(<5 \%)$ does not permit statistical analysis.

Higher growth rates have been observed for other mahogany species, such as Big-Leaf Mahogany (Swietenia macrophylla) in monospecific plantations (GUIMARÃES NETO et al., 2004), but these conditions also made the trees more susceptible to pest damage. Our experiment suggests that a mixed-species plantation may reduce the prevalence of $\mathrm{H}$. grandella, but will result in an increase of intra-specific competition causing reduced growth at higher seedling densities. 
Another important factor affecting the growth patterns of $C$. fissilis was the size of the clearing area. Stem diameter development was significantly higher only in larger clearings, but the opposite was true for seedling height. Even though $C$. fissilis is considered to have moderate tolerance to shading, these results may be explained by competition for light. Previous studies indicate that $C$. fissilis has higher survival rates (SOUZA, 1981) and improved growth patterns (GUARINO; SCARIOT, 2012) under moderate light intensities and can adapt its leaf morphology to such conditions (PAULILO et al., 2007). However, the combination of lateral shadowing and top-canopy lighting in smaller clearings may stimulate vertical growth in earlier stages of development (MAYHEW; NEWTON, 1998), while stem growth seems be prioritised in larger clearings with abundant light.

Overall, our study provided the first information about the viability of plantations of $C$. fissilis in combination with $P$. taeda. Although, other factors such as regional climate conditions and soil characteristics would need to be considered. Frost damage is a clear limiting factor, while rainfall may also have important consequences for seedling development (RUIZ et al., 2013) and pest susceptibility (MORGAN; SURATMO, 1976). There are also reports that compacted soils with reduced drainage capacity may affect the growth and survival of Cedrella species (MARSHALL, 1939).

Finally, we cared especially for the role of genetic variability in this study, but the selection of more adequate genetic material requires further attention. Future studies that aim to further develop silvicultural recommendations for $C$. fissilis should take all of these factors into account and frame them within the local socio-economic conditions of the study region (our focus on P. taeda derives from its importance within the study region). By doing this, land owners are more likely to adopt recommendations and improve local forestry practices (WALTERS et al., 2005).

\section{CONCLUSIONS}

(1) The cover provided by another species in the mixed-species forest plantations, at four years of age, may improve the survival rate of $C$. fissilis by reducing susceptibility to pests and frost damage, and;

(2) C. fissilis should be planted in small clearings $\left(\sim 10 \mathrm{~m}^{2}\right)$ as this significantly improves growth rates without negatively effecting survival.

(3) We registered high branching rates of $C$. fissilis under most experimental settings, which is a sign of development stress.

(4) Further research should focus on identifying management techniques that reduce stress levels during the growth stage, testing the effects of associating $C$. fissilis with different tree species, selecting appropriate genetic material for different environmental conditions, and working with land managers to integrate the most adequate silvicultural techniques into local practices.

\section{ACKONWLEDGEMENTS}

We would like to thank for fieldwork support: Ulisses Ribas Jr., Diego Fernando Roters and Fernanda Silveira; and research staff from Battistella Florestal and Valor Florestal companies. We also thank: Fabrício Antonio Biernaski for planning and installing the experiments; Laboratory of Genetics and Forest Improvement (LAMEF) of Federal University of Paraná (UFPR) for practical and theoretical support; the Empresa de Pesquisa Agropecuária e Extensão Rural de Santa Catarina (EPAGRI) for providing climate data. ACC received a PhD and a Post Doctoral (99999.006171/2014-01) scholarships from CAPES Foundation.

\section{REFERENCES}

ABRAF - ASSOCIAÇÃO BRASILEIRA DE PRODUTORES DE FLORESTAS PLANTADAS (ABRAF). Anuário estatístico ABRAF 2013: ano base 2012. Brasília, 2013. 148 p.

AGRAWAL, A.; CHHATRE, A.; HARDIN, R. Changing governance of the world's forests. Science, v. 320, n. 5882, p. 1460-1462, 2008.

BIONDI, D.; LEAL, L.; COBALCHINI, J. L. Tratamentos silviculturais em mudas de Allophylus edulis (A.St.-Hil., Cambess. \& A. Juss.) Radlk. para arborização de ruas. Revista Floresta, Curitiba, v. 37, n. 3, 2007. 
CARVALHO, P. E. R. Espécies arbóreas brasileiras. Colombo: Embrapa, 2003. Disponível em: < http://www. cnpf.embrapa.br/pesquisa/efb/index especies.htm >. Access: 26 nov. 2013.

CARVALHO, P. E. R. Comparação de espécies nativas, em plantio em linhas em capoeira, na região de Irati PR, resultados aos sete anos. Boletim de Pesquisa Florestal, Colombo, n. 5, p. 53-68, 1982.

CARVALHO, P. E. R. Competição entre espécies florestais nativas em Irati - PR, cinco anos após o plantio. Boletim de Pesquisa Florestal, Colombo, n. 2, p.41-56, 1981.

CARVALHO, P. E. R. Algumas características ecológicas e silviculturais de quatro espécies florestais do Estado do Paraná. 171 f. Dissertação (Mestrado) - Universidade Federal do Paraná, Curitiba, 1978.

CUSATIS, A. C.; TRAZZI, P. A.; DOBNER JR, M.; HIGA, A. R. Dendroecologia de Cedrela fissilis na Floresta Ombrófila Mista. Pesquisa Florestal Brasileira, Colombo, v. 33, p. 287-297, 2013.

D'OLIVEIRA, M. V. N. Artificial regeneration in gaps and skidding trails after mechanised forest exploitation in Acre, Brazil. Forest ecology and management, v. 127, n. 1, p. 67-76, 2000.

GUARINO, E. S. G.; SCARIOT, A. O. Tree seedling survival and growth in logged and undisturbed seasonal deciduous forest fragments in central Brazil. Journal of forest research, v. 17, n. 2, p. 193-201, 2012.

GUIMARÃES NETO, A. B.; FELFILI, J. M.; SILVA, G. F.; MAZZEI, L.; FAGG, C. W.; NOGUEIRA, P. E. Avaliação do plantio homogêneo de mogno, Swietenia macrophylla King, em comparação com o plantio consorciado com Eucalyptus urophylla S. T. Blake, após 40 meses de idade. Revista Árvore, Viçosa, v. 28, n.6, p. 777-784, 2004.

HIGA, R. C. V.; HIGA, A. R.; TREVISAN, R.; SOUZA, M. V. R. de. Resistência e resiliência a geadas em Eucalyptus dunnii Maiden plantados em Campo do Tenente, PR. Boletim de Pesquisa Florestal, Colombo, n. 40, p. 6776, 2000.

HIGA, A. R.; SILVA, L. D. Planejamento e implantação de pomares de sementes de espécies florestais nativas. In: HIGA, A. R., SILVA, L. D. Pomar de sementes de espécies florestais nativas. Curitiba: Fundação de Pesquisas Florestais do Paraná, 2006.

INOUE, M. T. Ensaio de procedência de Cedrela em Santo Antônio da Platina, PR. Floresta, Curitiba, v. 4, n. 2, p. 49-57, 1972.

INPE - INSTITUTO NACIONAL DE PESQUISAS ESPACIAIS. Estação Meteorológica de Rio Negrinho - Santa Catarina. Rio de Janeiro: INPE, 2009.

JOHNSON, J.; TARIMA, J. M. Seleccion de especies para uso en cortinas rompevientos en Santa Cruz, Bolivia. Santa Cruz: CIAT / MBAT, 1995. 83 p. (CIAT / MBAT. Informe Tecnico, 24).

KAGEYAMA, P. Y.; CASTRO, C. F. A. Sucessão secundária, estrutura genética e plantações de espécies arbóreas nativas. IPEF, Piracicaba, n. 41/42, p. 83- 93, 1989.

LAMB, D.; ERSKINE, P. D.; PARROTTA, J. A. Restoration of degraded tropical forest landscapes. Science, v. 310, n. 5754, p. 1628-1632, 2005.

MARSHALL, R. C. Silviculture of the trees of Trinidad and Tobago. Oxford: Oxford University Press, 1939.

MAYHEW, J. E.; NEWTON, A. C. The silviculture of mahogany. Wallingford: CABI, 1998. 226 p.

MORGAN, F. D.; SURATMO, F. G. Host preferences of Hypsipyla robusta (Moore) (Lepidoptera:Pyralidae) in West Jarva. Australian Forestry, v. 39, n. 2, p.103-112, 1976.

MOSTACEDO, B.; FREDERICKSEN, T. S. Regeneration status of important tropical forest tree species in Bolivia: assessment and recommendations. Forest Ecology and Management, v. 124, n. 2, p. 263-273, 1999. 
Cusatis et al. - Survival and growth of Cedrela fissilis (Vell.) in mixed-species forest plantations

NOBLE, I. R.; DIRZO, R. Forests as human-dominated ecosystems. Science, v. 277, n. 5325, p. 522-525, 1997.

PAULILO, M. T. S. Responses to light changes in tropical seedlings of the Brazilian Atlantic rainforest tree species Cecropia glazioui (Cecropiaceae) and Cedrela fissilis (Meliaceae). Australian journal of botany, v. 55, n. 8, p. 795-802, 2008.

PEARCE, D. W. The economic value of forest ecosystems. Ecosystem health, v. 7, n. 4, p. 284-296, 2001.

RESENDE, M. D. V. SELEGEN-REML/BLUP: sistema estatístico e seleção genética computadorizada via modelos lineares mistos. Colombo: Embrapa Florestas, 2007.

RESENDE, M. D. V. Predição de valores genéticos, componentes de variância, delineamentos de cruzamento e estrutura de populações no melhoramento florestal. 434 f. Tese (Doutorado) - Setor de Ciências Biológicas, Universidade Federal do Paraná, Curitiba, 1999.

RESENDE, M. D. V.; STURION, J. A. Delineamento e análise estatística de experimentos em silvicultura: efeitos genotípicos, erros aleatórios e estimadores melhorados para média de tratamentos. Boletim de Pesquisa Florestal, Colombo, n. 41, p. 67 - 73, 2000.

RUIZ, V. E.; MELONI, D. A.; FORNES, L. F.; ORDANO, M.; HILIAL, M. PRADO, F. E. Seedling growth and water relations of three Cedrela species sourced from five provenances: response to simulated rainfall reductions. Agroforestry systems, v. 87, n. 5, p. 1005-1021, 2013.

RUSCHEL, A. R.; NODARI, E. S.; GUERRA, M. P.; NODARI, R. O. Evolução do uso e valorização das espécies madeiráveis da Floresta Estacional Decidual do Alto-Uruguai, SC. Ciência Florestal, Santa Maria, v. 13, n. 1, p. 153-166, 2003.

SOARES FILHO, B. S. Impacto da Revisão do Código Florestal: como viabilizar o grande desafio adiante? [Brasília]: Secretaria de Assuntos Estratégicos, [2013]. Disponível em: < http://www.sae.gov.br/site/wpcontent/uploads/Artigo-codigo-florestal.pdf > Access: 08 dez.13.

SOUZA, L. J. B. Fotomorfose e crescimento de Cedrela fissilis Vell. no viveiro e no plantio de enriquecimento em linhas. 132 f. Dissertação (Mestrado em Engenharia Florestal) - Setor de Ciências Agrárias, Universidade Federal do Paraná, Curitiba, 1981.

TOLEDO FILHO, D. V.; PARENTE, P. R. Essências indígenas sombreadas. Silvicultura em São Paulo, São Paulo, v. 16A, pt. 2, p. 948-58, 1982.

WALTERS, B. B.; SABOGAL, C.; SNOOK, L. K.; ALMEIDA, E. Constraints and opportunities for better silvicultural practice in tropical forestry: an interdisciplinary approach. Forest Ecology and Management, v. 209, n. 1, p. 3-18, 2005.

WEAVER, P. L.; BAUER, G. P. Growth, survival and shoot borer damage in mahogany plantings in the Luquillo Forest in Puerto Rico. Turrialba, San José, v. 36, n. 4, 509-522, 1986.

WRIGHT, S. J. The future of tropical forests. Annals of the New York Academy of Sciences, v. 1195, n. 1, p. $1-27,2010$.

WRIGHT, S. J. Tropical forests in a changing environment. Trends in Ecology \& Evolution, v. 20, n. 10, p. 553-560, 2005.

Received 2016/10/17

Accepted 2017/12/19 